\title{
Ruanda
}

\section{Diagnostic Review of}

Consumer Protection

and Financial Literacy

Volume I: Key Findings and Recommendations

(4HE WORLD BANK 



\section{CURRENCY AND EQUIVALENT UNITS}

(As of November 2013)

Currency Unit = Rwandan Franc (RWF)

US\$1 = 673.96 RWF

\section{GOVERNMENT FISCAL YEAR}

January 1 - December 31

\section{ACRONYMS AND ABBREVIATIONS}

$\begin{array}{ll}\text { ADR } & \text { Alternative Dispute Resolution } \\ \text { AMIR } & \text { Association of Microfinance Institutions in Rwanda } \\ \text { APR } & \text { Annual Percentage Rate } \\ \text { ASSAR } & \text { Rwanda Insurers Association } \\ \text { ATM } & \text { Automated Teller Machine } \\ \text { BNR } & \text { National Bank of Rwanda } \\ \text { CCP } & \text { Competition and Consumer Protection } \\ \text { CPFL } & \text { Consumer Protection and Financial Literacy } \\ \text { CRB } & \text { Credit Reference Bureau (CRB) } \\ \text { EIR } & \text { Effective Interest Rate } \\ \text { FSDP II } & \text { Financial Sector Development Strategy for Rwanda } \\ \text { FinCap } & \text { Financial Capability Survey } \\ \text { MFI } & \text { Microfinance Institution } \\ \text { MINECOFIN } & \text { Ministry of Finance and Economic Planning } \\ \text { POS } & \text { Point of Sale } \\ \text { RBA } & \text { Rwanda Bankers Association } \\ \text { RCA } & \text { Rwanda Cooperative Agency } \\ \text { SACCO } & \text { Savings and Credit Cooperative Organization } \\ \text { VSLAs } & \text { village savings and loans associations }\end{array}$

\section{Disclaimer}

This Diagnostic Review is a product of the staff of the International Bank for Reconstruction and Development/the World Bank. The findings, interpretations and conclusions expressed herein do not necessarily reflect the views of the executive directors of the World Bank or the governments they represent. 


\section{ACKNOWLEDGEMENTS}

A World Bank team visited Kigali, Rwanda, during July 10-19, 2013, to conduct a Diagnostic Review on Consumer Protection and Financial Literacy (CPFL). The diagnostic consisted of banking and microfinance modules and a desk review on insurance. The review was undertaken in response to a request for World Bank (WB) technical assistance in the field of financial consumer protection made by the National Bank of Rwanda (BNR) in November 2012.

The team was led by Leyla Castillo (Financial Sector Specialist, FFIMS), and included Rosamund Grady (Sr. Financial Sector Specialist, FFIMS), David Grace (Consultant, Microfinance Expert), and Karen Den-Toll (Consultant, Insurance and Pensions Expert). Gunhild Berg (Financial Sector Specialist, AFTFE) provided valuable inputs and guidance to the team. Sebnem Sener (Project Officer, FFIDR) and Adetola Adenuga (Financial Analyst, FFIMS) provided inputs and support during the preparation of the present report.

The mission held meetings with representatives of relevant stakeholders, including the National Bank of Rwanda (BNR), Ministry of Finance and Economic Development (MINECOFIN), Ministry of Trade and Industry (MINICOM), Office of the Ombudsman, Rwanda Cooperative Agency (RCA), other government entities and public agencies, market players, industry associations, consumer associations and professional bodies.

The team has benefited from the overall guidance of Carolyn Turk (Country Manager) and Douglas Pearce (Practice Manager, FFIDR). Peer review comments were received from Angela Prigozhina (Country Sector Coordinator, ECSPF), Craig Thorburn (Lead Insurance Specialist, FCMNB) and Yoko Doi (Sr. Financial Sector Specialist, AFTFE).

The team would like to express its appreciation to the Rwandan authorities for their cooperation and collaboration during the preparation of the review. The project team would also like to thank all those who so generously contributed to the final report.

The review was prepared as part of the SECO funded Consumer Protection and Financial Literacy program of the World Bank and received complementary funding from the World Bank Africa Region Vice Presidency.

The review of the banking and microfinance sectors was based on information and data collected during the mission from publicly available data. The review of the insurance sector was conducted through a desk review using data provided by BNR through data requests and questionnaires, and the analysis is therefore constrained by it. 


\section{Contents}

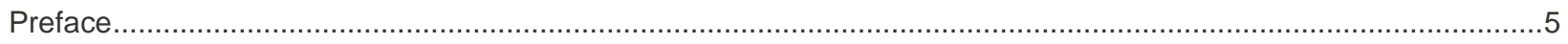

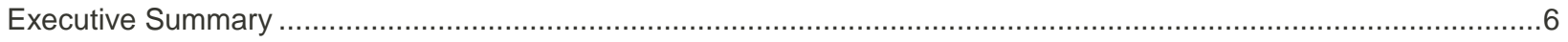

Rwanda: Consumer Protection and Financial Literacy Diagnostic Review ................................................... 9

General Framework for Financial Consumer Protection in Rwanda.........................................................13

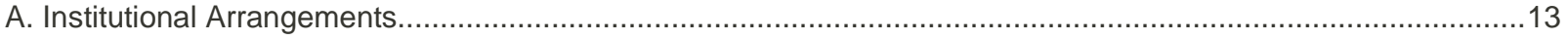

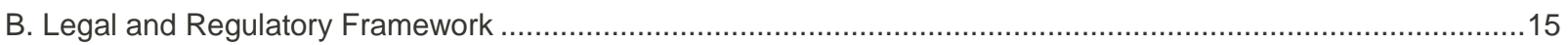

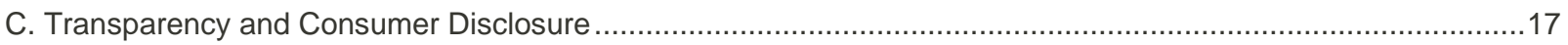

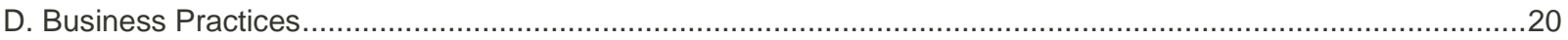

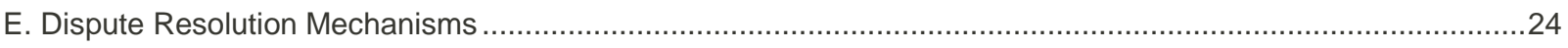

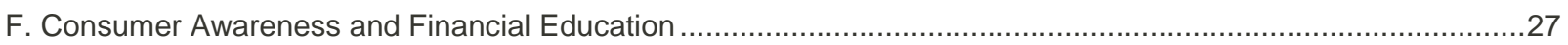

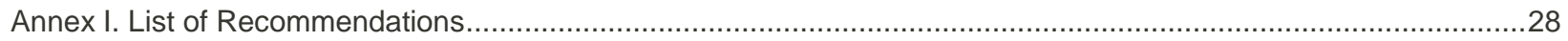

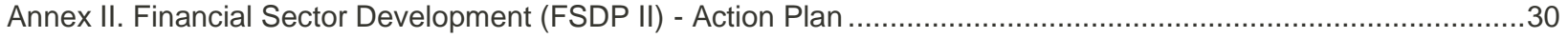

\section{Tables}

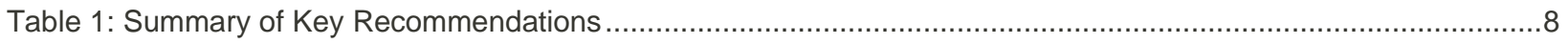

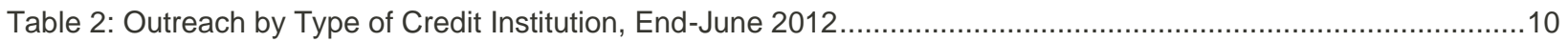

Table 3: Access to Formal Financial Services: Selected African Countries ...................................................11

\section{Boxes}

Box 1: Models of Institutional Set up for Consumer Protection Regulation and Supervision...................................14

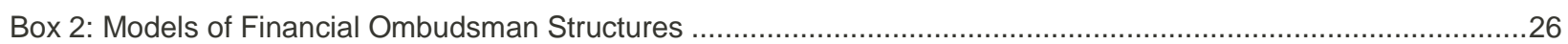




\section{Preface}

The CPFL Review is part of the World Bank Program on Consumer Protection and Financial Literacy, which seeks to identify key measures for strengthening financial consumer protection to help build consumer trust in the financial sector and expand the confidence of households to wisely use financial services.

CPFL Reviews against Good Practices have been conducted by the World Bank in both middle- and lowincome countries. These include Armenia, Azerbaijan, Bosnia and Herzegovina, Bulgaria, Croatia, the Czech Republic, Kazakhstan, Kosovo, Latvia, Lithuania, Malawi, Mongolia, Mozambique, Nicaragua, Pakistan, Peru, Romania, the Russian Federation, South Africa, Slovakia, Tajikistan, Tanzania, Ukraine and Zambia.

The main objective of the review is to assess the legal, regulatory and institutional frameworks for financial consumer protection in a country, with reference to international practices. The review addresses the following issues: (1) legal, regulatory and institutional frameworks, (2) transparency and disclosure of information, (3) retail business practices of financial institutions, (4) complaints and dispute resolution mechanisms, and (5) consumer awareness and education regarding the use of financial services along with consumers' rights and responsibilities, providing prioritized recommendations in these areas.
The review is based on compliance with the principles set forth in Good Practices for Financial Consumer Protection $^{1}$, developed by the World Bank using international benchmarks, such as the principles released by the Basel Committee, IOSCO and IAIS and OECD recommendations for financial education and awareness on pensions, insurance and credit products. Good Practices incorporates provisions of directives, laws, regulations and codes of business practices from the EU, United States, Australia, Canada, France, Ireland, Malaysia, Mexico, New Zealand, Peru and South Africa.

The CPFL Review includes a detailed assessment of each relevant financial segment consistent with Good Practices (Volume II), and a report summarizing the key findings for the assessment and prioritized recommendations (Volume I). ${ }^{1}$ http://responsiblefinance.worldbank.org/ /media/GIAWB/FL/
Documents/Misc/Good-practices-for-financial-consumer-
protection.pdf 


\section{Executive Summary}

The World Bank has developed the Good Practices for Consumer Protection and Financial Literacy as an assessment tool for country diagnostic reviews. The CPFL Review is part of the World Bank Program on Consumer Protection and Financial Literacy, which seeks to identify key measures for strengthening financial consumer protection to help build consumer trust in the financial sector and expand the confidence of households and businesses to wisely use financial services. CPFL Reviews against Good Practices have been conducted by the World Bank in more than 20 countries worldwide including middle- and low-income countries $^{2}$.

The existence of a sound financial consumer protection framework is fundamental to increasing access to and usage of financial services in Rwanda and the quality of those financial services, along with supporting further financial sector deepening. Financial consumer protection is a necessary precursor to building trust in the formal financial sector and thus in encouraging financial inclusion. Further, consumer protection helps ensure that expanded access benefits consumers and the economy as a whole. This is because while increased access can result in significant economic and societal benefits, it can be neutral or even harmful if consumers are not able to (i) exercise their rights as consumers, (ii) select the financial products that suit them best and (iii) be protected from mis-selling, fraud and other market abuses.

\section{PRELIMINARY FINDINGS}

The legislative and regulatory framework for financial consumer protection is at a very early stage of development. There are strong consumer protection provisions in the sector regulation such as the electronic money transfer and electronic transmission, credit information and the Market Conduct Regulation for the insurance industry. Pension sector laws lag behind other areas, with a draft pensions law before Parliament at the time of writing. However, the overall institutional framework for financial consumer protection in Rwanda in the banking, microfinance, and insurance sectors is fragmented because of a lack of clearly defined roles and responsibilities among institutions and unclear enforcement capacity. Although there has been an impressive array of financial sector laws passed by the Parliament of Rwanda over the last five years, the laws relevant to consumer protection in the financial sector are very limited and in some cases overlapping. BNR's consumer protection responsibilities overlap with those of the Ministry of Trade and Industry under the Competition and Consumer Protection Law 2012 (CCP Law) and the new Competition and Consumer Protection Regulatory Body.

Banks and microfinance institutions engage in practices that are detrimental to consumers and affect their confidence in and usage of the formal financial sector. Some of the issues observed include, (i) a lack of transparency in consumer contracts, (ii) anti-competitive fee-charging practices for different types of financial services that may limit financial inclusion, (iii) charging flat interest rates as opposed to declining balance interest rates by some microfinance institutions, which is both unfair and likely to mislead consumers when nominal rates are advertised and (iv) the lack of a functioning internal or external dispute resolution system.

\section{RECOMMENDATIONS}

Preliminary findings and recommendations presented in this report cover six areas, namely, (i) institutional arrangements, (ii) the legal and regulatory frameworks, (iii) transparency and disclosure, (iv) business practices, (v) complaints-handling and dispute-resolution mechanisms and (vi) consumer awareness and financial education.

In terms of institutional arrangements, consideration should be given to clarify BNR's primary responsibility for supervision of laws and regulations applicable to consumer protection in the financial sector. This may require providing that the Competition and Consumer Protection Law 2012

\footnotetext{
${ }^{2}$ See Annex I for more information.
} 
does not apply to financial services ${ }^{3}$, thereby limiting its powers with regards to financial institutions and financial services, and to clarify the banking legislation to expand and delineate the powers of the BNR.

- Banking Sector: The main recommendations for the banking sector include: 1) the introduction of comprehensive disclosure requirements, mandating that information be provided to retail bank customers about the products and services they need, especially the disclosure of effective interest rates and total credit rates, and 2) a review of fees charged by banks to assess whether they are anti-competitive or inconsistent with the financial inclusion objectives of the government. These recommendations are designed to build trust in and increase the usage of the formal financial sector and to encourage financial inclusion, while at encouraging competition in the banking industry.

- Microfinance Sector: The main recommendations for the microfinance sector include the following: 1) requiring up-front disclosure of all terms and conditions, nominal rates, fees and commissions together with disclosure of the effective interest rates reflecting all interest charges and fees and total credit cost; 2) clarify the institutional arrangements and related regulatory regime concerning the supervision of consumer protection issues for MFIs/SACCOs; and 3) to educate MFIs/SACCOs, BNR/RCA and consumers on the fundamentals of consumer protection and related rights and responsibilities. Industry associations also have a role to play in promoting codes of conduct, increasing consumer awareness and complementing ongoing efforts on the financial education of consumers. Together these changes will facilitate compliance with and supervision of consumer protection requirements and create better-informed consumers, financial institutions and regulators who understand the importance of consumer trust for sustained financial access.

- Insurance Sector. The main recommendations for the insurance sector include the following: 1) conducting an education campaign for potential policy holders to educate them on the features and benefits of insurance products (this is particularly important for micro insurance); 2) implementing appropriate initiatives to ensure that consumers understand the insurance product they are acquiring, such as a Key Features Statement that explains the key features of the policies or a verbal disclosure in the case of consumers with lower levels of literacy; and 3) conduct research to identify the role of various participants in the insurance market (including MFIs, banks, and SACCOs) and ensure all such participants are subject to appropriate rules and oversight. The design of effective methods for financial education can be informed by the new evidence and insights on financial education produced recently by the World Bank. These recommendations are designed to encourage an environment in which the insurance industry can flourish because consumers understand the nature of insurance and the potential benefits, and participants in the insurance sector are appropriately regulated.

- Pensions Sector. Rwanda's pension law was only in draft form at the time of review. For this reason, it is recommended that while the law is implemented, the BNR staff receive appropriate training in pension's supervision, particularly concerning consumer protection matters. It is likely that the development of the pensions sector will lead to an increase in activity in the life insurance sector, in particular for annuity and long-term investment products.

\section{Cross-cutting recommendations to improve the} overall CPFL framework in Rwanda include:

a) Financial Ombudsman: Clarify the powers of the office of the ombudsman concerning financial services and make binding decisions in relation to disputes and claims between financial institutions and customers.

b) Code of Conduct: Promote and support industry codes of conduct with treatment of disclosure, complaints, product appropriateness and other business areas strengthened, enforced and widely disseminated.

c) Financial Education: Encourage all stakeholders to complement ongoing financial education and literacy efforts to increase consumer awareness about their rights and responsibilities.

\footnotetext{
${ }^{3}$ This revision is with the caveat that the law will cover financial services in the area of competition but not consumer protection.
} 
Table 1 below lists the main recommendations and priority actions to enhance the current framework for financial consumer protection in Rwanda. The comprehensive list of recommendations is presented in Annex I of the present volume. The complete assessment is presented in two documents: the first document (Volume I) presents a summary of the key findings and recommendations, and the second document (Volume II) is presented in the form of a background technical note that assesses each sector against the Good Practices for Financial Consumer Protection principles developed by the World Bank.

\section{Table 1: Summary of Key Recommendations}

\begin{tabular}{|c|c|c|c|}
\hline Area & Recommendation & Responsibility & Term* \\
\hline $\begin{array}{l}\text { Institutional } \\
\text { Arrangements }\end{array}$ & $\begin{array}{l}\text { Clarify the roles of BNR, ombudsman, the forthcoming } \\
\text { Competition and Consumer Protection Regulatory Body and } \\
\text { RCA (for SACCOs) as these roles relate to consumer } \\
\text { protection rule-making, enforcement and dispute resolution in } \\
\text { the financial sector. } \\
\text { BNR should be given primary responsibility for supervision of } \\
\text { laws and regulations applicable to consumer protection in the } \\
\text { financial sector. } \\
\text { BNR staff should receive training on consumer protection } \\
\text { issues. A separate unit within BNR may be considered whose } \\
\text { primary responsibility would be supervising consumer } \\
\text { protection laws. }\end{array}$ & BNR & ST \\
\hline \multirow{2}{*}{$\begin{array}{l}\text { Legal and } \\
\text { Regulatory } \\
\text { Framework }\end{array}$} & $\begin{array}{l}\text { Consider implementing a cohesive financial consumer } \\
\text { protection framework that applies to banks, MFIs, SACCOs, } \\
\text { insurance companies, securities, pension schemes and the } \\
\text { brokers and agents of such institutions. }\end{array}$ & BNR & MT \\
\hline & $\begin{array}{l}\text { Consider conducting further analytical work to assess the need } \\
\text { to implement a personal insolvency law to provide for the } \\
\text { degree of recourse and assets that can be claimed upon } \\
\text { seizure of collateral. }\end{array}$ & MOJ & MT \\
\hline \multirow{2}{*}{$\begin{array}{l}\text { Transparency } \\
\text { and Disclosure } \\
\text { of Information }\end{array}$} & $\begin{array}{l}\text { Require all fees, charges, penalties, rates and commissions to } \\
\text { be disclosed in a manner understood by the average } \\
\text { consumer. }\end{array}$ & BNR & ST \\
\hline & $\begin{array}{l}\text { Require disclosure of an effective interest rate for comparison } \\
\text { purposes and on the basis of declining balances. }\end{array}$ & BNR & ST \\
\hline \multirow{2}{*}{$\begin{array}{l}\text { Business } \\
\text { Practices }\end{array}$} & $\begin{array}{l}\text { Promote competition in the banking space by enabling } \\
\text { consumers in banks, MFIs and SACCOs to close deposit } \\
\text { accounts and pre-pay or move loans with minimal time and } \\
\text { cost burden. }\end{array}$ & BNR/ RDB & MT \\
\hline & $\begin{array}{l}\text { Require that mortgagors be given warnings about the } \\
\text { consequences of default (including the possibility of losing their } \\
\text { homes) and otherwise ensure there is sufficient due process in } \\
\text { the repossession of collateral. }\end{array}$ & BNR & ST \\
\hline $\begin{array}{l}\text { Dispute } \\
\text { Resolution } \\
\text { Mechanisms }\end{array}$ & $\begin{array}{l}\text { Consolidate dispute resolution for the financial sector in a well- } \\
\text { trained, appropriately staffed and sufficiently empowered unit } \\
\text { of the national ombudsman. This includes making its findings } \\
\text { binding and ensuring that RCA and BNR relinquish these roles. }\end{array}$ & OMB & MT \\
\hline $\begin{array}{l}\text { Financial } \\
\text { Education }\end{array}$ & $\begin{array}{l}\text { Continue with financial awareness campaigns related to the } \\
\text { use of financial products and basic financial concepts that are } \\
\text { understandable for the average consumer. }\end{array}$ & BNR & LT \\
\hline
\end{tabular}

*ST: Short Term; MT: Medium Term; LT: Long Term

${ }^{4}$ Within this document, this is referred to as a framework that could take the form of a law or regulation depending on BNR's assessments. 


\section{Rwanda: Consumer Protection and Financial Literacy Diagnostic Review}

\section{INTRODUCTION}

The existence of a sound financial consumer protection framework is fundamental for expanding access to financial services and supporting further financial-sector deepening in Rwanda. Ensuring the existence of sound business practices, disclosure regimes and redress mechanisms to address the imbalance of power between financial institutions and their customers constitutes the fundamental pillars of a consumer protection regime and expands access to financial services. While increased access to finance can result in significant economic and societal benefits, it can be neutral or even harmful if consumers are unable to do the following: (i) exercise their rights as consumers; (ii) select the financial products that suit them best and (iii) be protected from mis-selling, fraud and other market abuses in violation of financial service providers' statutory and regulatory obligations toward them. As a result, the use of financial services (for example savings and new technologies such as mobile banking) by new and existing customers is often held back and consumers are less able to benefit fully from financial services, while the risk of harmful impacts for consumers and financial institutions, such as consumer overindebtedness and mis-selling scandals increases.

A sound consumer protection regime is complemented with sound prudential regulation and supervision. Prudential requirements are intended to ensure that the financial promises made by financial institutions are met, while proper oversight by financial authorities ensures adherence to such standards. In this sense, actions to strengthen the regulatory framework and practice of supervision contribute directly to protecting the interests of consumers.

The main objective of the CPFL Review in Rwanda is to assess the legal, regulatory and institutional frameworks for financial consumer protection with reference to the World Bank's Good Practices for
CPFL. The CPFL Review is a detailed assessment based on compliance with a set of principles delineated in Good Practices for Financial Consumer Protection ${ }^{5}$ covering key five areas: (1) legal, regulatory and institutional frameworks; (2) transparency and disclosure of information; (3) retail business practices of financial institutions; (4) complaints and dispute resolution mechanisms; and (5) consumer awareness and education. The Good Practices principles were developed by the World Bank using international benchmarks, including the principles released by the Basel Committee, IOSCO and IAIS, along with the OECD recommendations for financial education and awareness on pensions, insurance and credit products. As such, the CPFL review provides countries with a detailed diagnostic and recommendations for each of the listed Good Practices in different areas.

\section{CONTEXT}

The financial sector in Rwanda is at an early stage of development. Despite significant existing challenges, the institutional elements of an emerging and formal financial sector are in place. Bank and non-bank deposit-taking institutions, credit providers, insurance companies and a nascent industry of investment funds and capital markets firms are providing and expanding the range of products and services available in the market. A number of informal channels still co-exist filling an important gap in the provision of financial services (savings and credit) for the lower-income segment, and in particular in the rural areas.

The financial sector is bank-dominated in terms of total assets, mobilizing savings and lending with microfinance institutions (MFIs), including savings and credit cooperative organizations (SACCOs), playing an important outreach role. Similar to other East African countries, the insurance sector is still at an

\footnotetext{
${ }^{5}$ http://responsiblefinance.worldbank.org/ /media/GIAWB/FL/ Documents/Misc/Good-practices-for-financial-consumerprotection.pdf
} 
early stage of development. Private pension schemes have begun to develop in anticipation of the introduction of the legal framework, with the pending enactment of the new pension law expected to provide greater certainty and a foundation for expan- ding contractual savings. MFIs and SACCOs have been fundamental in bringing formal financial services to segments that were not previously served by the banking sector.

Table 2: Outreach by Type of Credit Institution, End-June 2012

\begin{tabular}{lccc} 
& $\begin{array}{c}\text { Service } \\
\text { points }\end{array}$ & $\begin{array}{c}\text { Number of deposit } \\
\text { accounts }\end{array}$ & $\begin{array}{c}\text { Number of } \\
\text { borrowers }\end{array}$ \\
\hline Banks & 301 & $1,283,466$ & 357,971 \\
- Of which, Banque Populaire du Rwanda & 118 & 842,831 & 143,374 \\
- Microfinance banks & 47 & 98,574 & 84,436 \\
Microfinance institutions & 683 & $1,775,533$ & 176,987 \\
- SACCOs & 608 & $1,468,063$ & 156,972 \\
-- Of which, Umurenge SACCOs & 513 & $1,211,726$ & 43,433 \\
- Other MFls & 75 & 307,470 & 20,015
\end{tabular}

Source: BNR.

Note: Numbers of accounts and borrowers include an element of double counting as individuals and companies may have multiple accounts.

The Rwandan government has made remarkable progress toward achieving its commitment regarding financial inclusion. As stated in Vision 2020 , the government's target is that 80 percent of the nation's adult population has access to formal financial services by 2017 and 90 percent by 2020 . According to Finscope 2012, formal financial inclusion doubled from 21 percent in 2008 to 42 percent in 2012. In addition, 72 percent of Rwandan adults are financially included (through formal and informal channels), 23 percent banked and 19 percent are non-bank formally served and 30 percent informally served. In 2012, 70.9 percent of the adult population saved, compared to 54 percent in 2008. Similarly, in 2012 the percentage of adults who borrowed was 58.5 compared to 27 in 2008 . There are 171 accounts at commercial banks per 1000 adults and 5.5 bank branches per 100,000 adults. Furthermore, a significant proportion of Rwandan population still uses informal mechanisms to manage their money. Informal inclusion increased from 39 percent in 2008 to 58 percent in 2012 .

Despite significant progress, access to finance remains one of the most binding constraints to business growth, poverty reduction and economic development. To date, 1.3 million Rwandan adults are still excluded and further increases beyond this level become increasingly challenging. The increase in financial inclusion rates has been attributed to the dramatic rise in the proportion of adults formally served during the measured period and includes the uptake of products offered by both banks and nonbank formal providers such as Umurenge SACCOS and insurance companies. The percentage of the adult population with SACCO products increased from 0 in 2008 to 22.3 in 2012, with 22 percent of adults in Rwanda having district-level SACCOs_referred to as Umurenge SACCO- products. The insurance uptake increased from 3 percent in 2008 to 7 percent in 2012.

Penetration of banking services remains on a relatively low level, while innovative payment mechanisms are being introduced by banks and telecom companies. The use of formal financial mechanisms to save money and obtain loans is relatively low when compared to the percentage of the total population saving or obtaining loans in the past year (Table 3). While these figures have similar trends in comparator countries, there is potential for further improvement. There are two new foreign commercial banks, 110 new bank service locations. Mobile banking and mobile money transfer (MTN) services have become widely available, and there is a new agency network for banks and MMT service providers. The number of accounts at commercial banks per 1000 adults is 171 , and the number of bank branches per 100,000 adults is 5.5. In terms of number of non-cash transactions, credit transfers and payment cards are the top two payment instruments; and in terms of value, checks and credit transfers. However, the annual per-capita usage of electronic payment transactions is very low- estimated to be 
around 0.5 . Usage of these payment mechanisms are growing at a faster rate than traditional electronic payment mechanisms and contribute to more than 5 percent of the overall electronic payment transactions in the country. Agents provide cash-in/cash-out services and register new customers (account openings). Government payments are predominantly made using cash and checks, with payments to government-like tax payments being made predominantly in cash.

Table 3: Access to Formal Financial Services: Selected African Countries

\begin{tabular}{lccccc}
\hline & $\begin{array}{c}\text { Account at } \\
\text { formal financial } \\
\text { institution } \\
\text { (\% age 15+) }\end{array}$ & $\begin{array}{c}\text { Saved any } \\
\text { money in the } \\
\text { past year } \\
(\% \text { age 15+) }\end{array}$ & $\begin{array}{c}\text { Saved at a } \\
\text { financial } \\
\text { institution in the } \\
\text { past year } \\
\text { (\% age 15+) }\end{array}$ & $\begin{array}{c}\text { Loan in the } \\
\text { past year } \\
\text { (\% age 15+) }\end{array}$ & $\begin{array}{c}\text { Loan from } \\
\text { financial } \\
\text { institution in the } \\
\text { past year } \\
\text { (\% age 15+) }\end{array}$ \\
\hline South Africa & 53.6 & 31.5 & 22.1 & 44.1 & 8.9 \\
Kenya & 42.3 & 42.3 & 23.3 & 67.4 & 9.7 \\
Mozambique & 39.9 & 42.6 & 17.5 & 41.3 & 5.9 \\
Rwanda & $\mathbf{3 2 . 8}$ & $\mathbf{3 0 . 5}$ & $\mathbf{1 7 . 8}$ & $\mathbf{3 8 . 5}$ & $\mathbf{8 . 4}$ \\
Botswana & 30.3 & 28.8 & 16.5 & 51.0 & 5.6 \\
Nigeria & 29.7 & 64.4 & 23.6 & 48.3 & 2.1 \\
Zambia & 21.4 & 32.2 & 11.8 & 48.0 & 6.1 \\
Uganda & 20.5 & 44.4 & 16.3 & 52.8 & 8.9 \\
Tanzania & 17.3 & 40.1 & 11.9 & 51.7 & 6.6 \\
Malawi & 16.5 & 33.0 & 8.2 & 51.3 & 9.2 \\
\hline Sub-Saharan Africa & $\mathbf{2 4 . 0}$ & $\mathbf{4 0 . 2}$ & $\mathbf{1 4 . 2}$ & $\mathbf{4 6 . 8}$ & $\mathbf{4 . 8}$ \\
\hline Low income & $\mathbf{2 3 . 7}$ & $\mathbf{2 9 . 9}$ & $\mathbf{1 1 . 5}$ & $\mathbf{4 4 . 1}$ & $\mathbf{1 1 . 4}$ \\
\hline
\end{tabular}

Source: Global Findex, 2011

Insurance penetration is very low and the market is at an early stage of development, Despite having doubled from 2006-2011, insurance penetration in Rwanda was just $2.3 \%$ in 2011 and is low even compared to some of its regional peers in East Africa $^{6}$. Under Vision 2020, the government of Rwanda's goal is to increase insurance penetration to $7 \%$. The reasons for a low insurance penetration seem varied, including the fact that 45 percent of the population still lives in poverty. Other reasons also include what some cite to be a shortage of skilled financial sector staff members, low levels of awareness of insurance in the community and low levels of marketing by insurers. The existence of 8 percent VAT on insurance premiums has also been cited as a key constraint for the sector's growth, a charge that does not apply elsewhere in the East African community.

\footnotetext{
${ }^{6}$ By comparison, Kenya's insurance penetration is 2.76 percent, the highest in the region.
}

MFIs and SACCOs ${ }^{7}$ make up an important part of the financial system serving 1.8 million or 26 percent of the economically active population. As of June 2013, there were 12 limited company MFIs, 63 employer or community based SACCOs and 416 Umurenge SACCOs. In addition, there are three commercial microfinance banks registered under the Banking Act and one cooperative bank that was previously the Army SACCO, which together serve approximately 154,000 individuals. By comparison, the largest non-bank limited company MFI has 117,000 clients and RWF 3.6 billion in assets. Informal savings and finance channels play an important role in serving financial needs of the

\footnotetext{
${ }^{7}$ For regulatory and licensing purposes, all SACCOs are technically classified as type 2 or type 3 MFIs. Throughout this document, we refer to both of them separately because of their different business practices and the additional regulatory and legal framework that SACCOs under the RCA and Cooperative Act.
} 
Rwandan population. The informal sector is made up of 760,000 users of village savings and loans associations (VSLAs), tontines, friends and families, local businesses providing lines of credit and a very small but unmeasured shadow banking system.

The informal sector is made up of 760,000 users of VSLAs, tontines, friends and families, local business providing lines of credit and a small but unmeasured shadow banking system. Shadow banking is a criminal offense under Article 642 of the Penal Code punishable by two to five years in jail. As such, loan sharking is limited and undetectable even in many rural areas.

The most dynamic part of the MFI sector continues to be the Umurenge SACCOs, which were started in 2009 and now serve 72 percent (1.3 million) of the clients in the combined MFI, existing SACCO and Umurenge SACCO industry. In the last 24 months, these 416 SACCOs have grown their assets 134 percent to RWF 46 billion. As lending among them has grown so have income and non-performing loans. Non-performing loans now stand at 7.3 percent (below the overall NPLs for all MFIs at 10 percent). Most important for these institutions and their 1.3 million members and their RWF 31.6 billion in deposits, 304 of the SACCOs are now financially viable without government subsidies. The remaining 112 are scheduled to stop receiving subsidies at the end of 2013. Importantly, as a group the Umurenge SACCOs has 26.3 percent capital to non-risk weighted assets.
A relatively low level of financial literacy in Rwanda constrains the demand for and use of financial services by a broader part of the population. Fifty-eight percent of adults indicated that they are scared that banks will seize their property if they borrowed from them ${ }^{8}$ and about 60 percent expressed the need for more information on how to keep money safe, how credit works and how to spend money wisely.

The government has recently developed a comprehensive financial education strategy as a critical factor to support the national agenda of financial inclusion-that is, increasing Rwandans' access and informed use of financial services. Results from a Financial Capability Survey (FinCap) conducted in 2012 suggest that there are some important capability challenges for Rwandans in terms of numeracy, cash flow management, future planning and the use of financial services. According to survey results, less than half of Rwandans gave correct answers to all four numeracy questions that test addition, subtraction, multiplication and division. The results also suggest that there is a disconnect between Rwandans' knowledge or awareness of cash-management practices and their behavior. Finally, the financial services data suggest that Rwandans use a mix of informal and formal financial services to manage their money. There is a prevalence of loans from family and friends and the use of store credit, which can have both positive and negative consequences for the borrowers. The implementation of the financial education strategy is embedded in the broader government agenda to improve financial inclusion.

\footnotetext{
${ }^{8}$ Compared to 14 percent for informal financial institutions and 35 per cent for MFIs.
} 


\title{
General Framework for Financial Consumer Protection in Rwanda
}

\author{
A. Institutional Arrangements
}

The overall institutional framework for financial consumer protection in Rwanda in the banking, microfinance and insurance sectors is fragmented because of a lack of clearly defined roles and responsibilities among different institutions and unclear enforcement capacity. The National Bank of Rwanda's (BNR) consumer protection responsibilities overlap with those of the Ministry of Trade and Industry under the Competition and Consumer Protection Law 2012 (CCP Law) and the new Competition and Consumer Protection Regulatory Body. BNR regulates and supervises all financial institutions, including MFIs and SACCOs ${ }^{9}$. However, BNR does not specifically allocate resources to supervision of the limited consumer protection laws that apply. There is accordingly no separation of supervision of prudential and consumer protection laws and it is not clear that the BNR has specialized expertise on consumer protection matters.

The CCP Law contains consumer protection provisions that apply to all types of "services" which would include financial services. Relevant provisions in the CCP Law include those relating to information to be given to consumers, advertising and prejudicial provisions that do not have any "tangible fairness. ${ }^{10}$ The Rwanda Cooperative Agency (RCA), a division of the Ministry of Trade and Industry, is

\footnotetext{
${ }^{9}$ The Rwanda Cooperative Agency (RCA) claims to have a role in resolving disputes between SACCOs and their members. However, nothing in the 2008 law Establishing Rwanda Cooperative Agency and Determining its Responsibilities, Organization and Function nor does the 2007 law Providing for the Establishment, Organization and Functioning of Cooperative Organization in Rwanda provide this power or duty to RCA. Despite it not being within the mandate of the Rwanda Cooperative Agency, they are handling 5 to 7 member complaints per month. The most frequent complaint (while not necessarily consumer protection related) is that SACCOs are not giving loans. BNR also receives complaints but it does not track the type of complaints.

${ }^{10}$ Articles 33, 34 and 39.
}

responsible for the registration, training and promotion of SACCOs. While still a proposal, it is likely that the national ombudsman will develop a new unit to handle financial sector cases, including financial consumer protection issues for banks, MFIs, insurance and pensions.

The relatively new insurance sector is supervised by BNR with only 12 staff members but with active steps being taken to build both capacity and resources. Supervision occurs through the Non-Bank Financial Institutions' (NBFI) Division of BNR, which is responsible for supervision of all insurance and pension financial institutions and other types of nonbank financial institutions. BNR has only been supervising since 2007 when supervision responsibilities were transferred from the Insurance Commission. Supervision is paid for through a levy on regulated entities (currently 12 percent of gross written premiums, although until recently it was a flat fee).

\section{KEY RECOMMENDATIONS}

Consideration should be given to providing that the Competition and Consumer Protection Law 2012 does not apply to financial services, so as to make it clear that BNR has primary responsibility for supervision of laws and regulations applicable to consumer protection in the financial sector. The objective would be to have an authoritative financial services consumer protection regulator for all financial sectors. This would achieve consistency of interpretation, minimize the risk of gaps in regulatory coverage and avoid any real or perceived conflict of interest for the supervisor. Another option would be to establish a market conduct regulator for the financial sector but this may not be practicable. Likewise, the roles of BNR, ombudsman, the forthcoming Competition and Consumer Protection Regulatory Body and RCA (for SACCOs) should be clarified as it relates to consumer protection rule-making, enforcement and dispute resolution in the financial sector. 
Regulation and supervision of financial consumer protection laws need to be properly resourced and separated from the prudential function to avoid conflicts between supervising financial institutions and their customers. A practicable way to achieve this would be to have a new unit responsible for consumer protection with a separate reporting line directly to the vice governor. Another option would be to have a completely separate financial services market conduct regulator, but that is not likely to be practical in the present context.

With the new pension law expected to be passed shortly, it is recommended that BNR consider whether it needs to increase its experience, education and focus on the sector in anticipation of further expansion in the industry. This could include a focus on training staff on private pensions' issues, in particular investment issues such as investment management, the reporting of investment returns and matters affecting consumer decisions during the pension fund life cycle, including deciding which fund to join, deciding on investment options, and making decisions on retirement products such as annuities.

Box 1: Models of Institutional Set up for Consumer Protection Regulation and Supervision

\section{Single Agency Approach.}

One institutional approach is to have prudential and consumer protection supervision allocated within the same supervisory agency. This is the case in Kazakhstan, where the Agency on Regulation and Supervision of Financial Market and Financial Organizations is statutorily responsible for both the stability of the financial sector and maintenance of financial consumer protection. In Malaysia, the Bank Negara Malaysia (central bank) is responsible for both prudential and consumer protection oversight of financial institutions (except securities). The two mandates are overseen by separate departments but in close coordination. Placing consumer protection in the same department as prudential supervision creates potential conflicts with the traditional and long-standing prudential supervisory roles that tend to dominate in allocation of resources and priorities. Prudential supervision, however, can provide useful early warning signals for business conduct supervision. International experience shows that if a supervisory agency adopts consumer protection as part of its mandate, business conduct supervision should be separated from prudential supervision and have adequate specialized staff and resources to perform its specialized responsibilities effectively to avoid conflicts of interest.

\section{Specialized Financial Consumer Protection Agency.}

Some countries have established one or more specialized regulators for financial consumer protection. Australia was the first country to set up a so-called "twin peak" structure where the market conduct regulator is responsible for overseeing the way in which market participants behave, while the other peak — the prudential regulator-is charged with overseeing the financial health, safety and soundness of market participants. This approach was followed by the Netherlands. Recent trends in financial consumer regulation point to the development of such specialized agencies, as seen in the creation of the Financial Consumer Agency of Canada (2001), the establishment of the Consumer Financial Protection Bureau in the United States (2011) and the proposed Financial Conduct Authority of the United Kingdom. Conflicts of interest can thereby be avoided between oversight that focuses on ensuring the stability of the financial system as a whole, and supervision that seeks to ensure that individual consumers of financial services are protected in the market. While this model has the advantage of clearly defined objectives and mandates of the respective agencies the challenge is to provide a new financial consumer protection agency with sufficient authority and credibility within the financial system.

\section{General Consumer Protection Body.}

A third approach is for a single agency with jurisdiction to cover general consumer protection issues to be required to include in its mandate consumer protection of financial products and services as well. This is the case in Brazil, where many basic consumer protection rights are guaranteed in the Consumer Protection Code. The Department for Consumer Protection and Defense (housed at the Ministry of Justice) has oversight over consumer protection in general, including financial consumer protection issues, although the Central Bank of Brazil covers some financial services issues not mentioned in the code. The challenge of the general consumer protection agency approach is to provide sufficient resources to handle financial services issues properly because the technical aspects of financial services require specialized staff with sector-specific knowledge, expertise and experience. 


\section{B. Legal and Regulatory Framework}

\section{BANKING SECTOR}

Rwanda has a wide range of financial sector laws and related regulations and directives that have implications for consumer protection in the banking sector in a number of respects. Relevant laws relate to regulation of the banking sector, competition and consumer protection generally, credit bureaus, mortgages and other security over land and movable property, electronic payments systems and transactions, use of agents to deliver financial services, dispute resolution, customer service delivery standards and negotiable instruments such as checks.

Although there has been an impressive array of financial sector laws passed by the Parliament of Rwanda over the last five years, the laws relevant to consumer protection in the financial sector are very limited and in some cases overlapping. Examples include the following:

- There are no requirements for disclosures in contracts for bank services. There is no requirement that contracts include all applicable interest rates, fees, charges and any other terms and no requirement that consumers be given a copy of their contract with sufficient time to read it before they sign it. There is also no requirement that consumers be given a summary of the key features of their contracts or periodic statements of account.

- There are no controls over fees that might limit competition, financial inclusion or otherwise be unfair. A consumer's ability to switch banks is likely to be hampered by the widespread practice of charging a prepayment fee of 5 percent of the unpaid balance if a customer wants to pay out a contract early.

- There is no requirement for a total cost of credit or effective interest rate to be provided to consumers to easily compare products. Such a rate could be a very useful tool to enhance the comparability of fixed-rate loan products.

- The Office of the Ombudsman does not have the clear power to make decisions on customer disputes that bind the financial institution concerned.
- There are no controls over debt collection practices in Rwanda and no requirement for debt collectors to be licensed.

- Consumers do not have to be warned of the consequences of giving mortgages or security over movable property. The new laws on mortgages and movable property allow a defaulting debtor's secured property to be sold within 60 days of the default notice for mortgages over land (such as the matrimonial home) or 30 days for a security over movable property (such as a car or livestock).

- There is no clear personal bankruptcy law in Rwanda that could be relied on to protect debtors who are in no position to pay their debts. Although there is an insolvency law, there is doubt as to whether it applies to consumers with personal debts.

- There are no comprehensive data protection laws in Rwanda, such as exist in many other countries. Kenya is an example of a country that is introducing such laws. A failure to have such laws may inhibit Rwanda's ability to engage in trans-border data flows and is of concern at a time when banking transactions are becoming increasingly electronic.

- There are overlapping provisions in the CCP Law and in the legislation supervised by BNR. There are BNR regulations concerning the disclosure of interest rates and fees and charges and the CCP Law also requires information to be given to consumers, which would include bank customers.

The above mentioned gaps and overlaps are of particular concern for Rwanda given the ambitious financial inclusion targets for 2017 and 2020, as outlined in the Financial Sector Development Strategy (FSDP II), and the rapid development of new banking services and distribution channels (such as agent banking, mobile money transfer services and mobile banking). These developments suggest the need for enhanced consumer protection measures and a comprehensive legal and regulatory regime to ensure trust in the financial sector. 


\section{MICROFINANCE SECTOR}

The existing legal and regulatory framework for consumer protection in the microfinance sector consist of six different laws, regulation, directives and guidelines for MFIs and seven for SACCOs. However, none of the existing regulations require the disclosure of fees, penalties or commissions, or to give the client a copy of contracts with terms and conditions, receive statements or protect the privacy of client's loan and savings information-aside from when reporting to the credit bureau. Although arguably the Competition and Consumer Protection Law requires disclosure of prices, it relates mostly to products and goods and services for households. Nonetheless, it was observed that there is some level of disclosure in MFIs/SACCOs.

The combination of not having a personal insolvency law and Article 21 of the Microfinance Regulation prohibiting a person who has defaulted on a loan from ever obtaining a loan again from any financial institution is punitive and may be limiting business creation. These provisions coupled with a system of full recourse loans, harsh penalties for overdrafts and a rapid 60-day, non-judicial process for seizing collateral creates a series of incentives that may encourage usage of informal financial services and limit excessive risktaking by entrepreneurs and individuals who have few consumer rights in laws or regulations.

\section{INSURANCE SECTOR}

Rwanda has been very active with the implementation of insurance reforms in the recent past and the Market Conduct Regulation contains strong consumer protection provisions for the insurance industry. In 2007, supervision transferred from the National Insurance Commission to the BNR. In 2008, the new insurance law required insurers to separate their short- and long-term businesses into different companies and increased capital requirements tenfold to RWF 1 billion. The Market Conduct Regulation contains provisions dealing with the insurers' and insurance intermediaries' duties to act with the utmost good faith, integrity, due care and diligence. There are also requirements for certain information to be given to the insured and for the insurer to have proper procedures and an effective mechanism to deal with claims and complaints handling. However, the CCP Law also contains consumer protection provisions that apply to all types of "services," which would include insurance and other financial services. Relevant provisions in the CCP Law include those relating to information to be given to consumers, advertising and prejudicial provisions, which do not have any "tangible fairness".

\section{RECOMMENDATIONS}

Consideration should be given to enacting provisions that provide a comprehensive regime for transparency and fairness in consumer contracts and related business practices. This might be done in a separate financial services law or in regulations made under sector-specific existing laws (e.g., the banking law). Such a law could include provisions dealing with contractual disclosures, anti-competitive fees, warnings about the effect of mortgages, unfair terms and disclosures of the total cost of credit interest rates. A transitional period of at least 12 months should be provided before the new regime comes into effect for institutions to adjust their systems and processes to new requirements. This would also allow proper time to conduct a public awareness campaign for consumers about the changes.

Consideration should be given to clarifying the powers of the Office of the Ombudsman in respect of financial services. In particular, it is proposed that the ombudsman should have clear powers to make binding decisions on financial services disputes.

Over time, consideration may be given to the enactment of new legislation regulating debt collectors, implementing best practices on data protection and providing clear personal bankruptcy laws. The current insolvency law only applies to companies. Advice should be sought on introducing a personal insolvency law, and Article 21 of the Microfinance Regulations should be eliminated. The experience of other countries suggests that an alternative approach may be more prudent, such as removing default records in the credit registry after a certain number of years.

Further, if the above recommendations are accepted, there would be a need for consequential changes to the CCP Law and certain BNR legislation. In particular, the CCP act would need to be amended so that relevant consumer protection provisions do not apply to financial services. Further, relevant aspects of the Disclosure of Interest and Fees and Charges Regulation 2011 and the Customer Service Delivery Directive 2012 need to be repealed. Further details of these recommendations are included in Parts $C$ and $D$ below. 


\section{Transparency and Consumer Disclosure}

There are limited regulatory requirements in terms of the information that needs to be disclosed to consumers of financial services regarding contractual terms and conditions. Due to a deficient legal framework, the type and amount of information that financial institutions present to their clients vary by institution.

The provision of clear, standardized and comparable information to consumers can be an effective mechanism to promote competition, bringing down the cost of financial products and services. However there is a lack of transparency on pricing of financial products and services. No official standard formula exists for comparing credit product prices, such as an effective interest rate (EIR) or an annual percentage rate (APR) and no disclosure obligations for additional costs such as administrative fees or insurance costs. This prevents consumers from comparing different credit products available to them.

\section{Transparency of Contract Terms}

There are no requirements for disclosures in contracts for financial services-apart from insurance-with one small exception. The only exception is the very limited and general disclosure requirement in the CCP Law. The relevant provisions relate to disclosure of information concerning the characteristics of the product or service and the contract conditions but are subject to the need for information expressed by the customer. ${ }^{11}$ Significantly, the Disclosure of Interest and Fees and Charges Regulation does not require the relevant information to be included in a contract. Rather the regulation requires information about interest rates, fees and charges to be displayed in local newspapers, bank premises, on the web and in a publically available brochure. With respect to insurance, there is opportunity for the disclosures to be improved.

Further, the current framework also does not address in any way the need to ensure customers understand the terms of the contracts they are

\footnotetext{
${ }^{11}$ Article 33.
}

signing and the features of the related products. This is of particular concern in a country such as Rwanda where there are low levels of financial literacy, high levels of illiteracy and where banking products available to customers are changing rapidly and becoming increasingly complex through their reliance on new technologies.

\section{Key Recommendations}

There should be a comprehensive contractual disclosure regime applied to financial services (including banking services). For banking services, this should include, at a minimum, the following: the amount borrowed, the applicable interest rate and total interest charges, the applicable default rate of interest, details of all fees and charges, information about whether interest rates are fixed or variable, the method of calculating interest charges (flat or on a declining basis), any applicable insurance premiums and commissions, details of any security given and a requirement to give reasonable notice of changes (say 20 days). This is the minimum information that should be given to customers if they are to be able to make an informed decision about the service and to be fully aware of their rights and responsibilities.

Contract documents could also be made comprehensible through summaries of key information, clear language and format and explanations from bank staff or insurance intermediaries in appropriate cases. This might be achieved through implementing the following specific recommendations:

- A key facts statement should be provided on the first page of every contract summarizing the key terms.

- Contracts should be both intelligible and legible.

- Contract documents should be explained to customers who would not otherwise understand them.

- Customers should be given time to consider documents before the contract is signed.

\section{Notice of Changes to Contracts}

Banks are required to inform the public and BNR of any changes to interest rates, fees and charges. However, no personal notice is required. This must be done "in fifteen days" and in accordance with Article 
3 of the Disclosure of Interest and Fees and Charges Regulation 2011, which requires publication in a local newspaper with wide distribution, on their websites, in a publicly available brochure and "outstandingly at the entrance of their premises." The publication must be made in the three official languages. There is also a requirement in the Law on Mortgages 2009 relating to notice of changes to variable rates. Article 10 provides that notice of any such change must be given to the mortgagor. It is not clear under the Law on Mortgages whether the notice has to be given in advance and there are no timing requirements. Further, there seem to be frequent breaches of the requirement to display the relevant changes in the three official languages at banks' business premises.

The new laws on mortgages and movable collateral make provision for secured property to be seized and sold on default within a very short time frame (60 days in the case of a mortgage over land and 30 days for security given over movable property). Further, there is no need for the mortgagee to take any action through the courts. While the business efficacy of the new requirements is recognized, there is a residual concern about whether consumers understand the implications of giving security over property and the consequences of default. This concern exists notwithstanding that it is understood banks will seek to assist debtors in financial difficulty by entering into new repayment arrangements.

The current regulatory framework does not require banks to give customers regular statements of account or updated account information on request. This information would enable customers to check for the accuracy of balances, debits and credits and facilitate management of their accounts. This is particularly important for long-term and revolving credit facilities (such as overdrafts and credit card contracts) and variable rate contracts.

\section{Key Recommendations}

There should be a requirement for advance notice to customers regarding changes to applicable interest rates and fees and charges. This notice should be given personally where it is practicable to do so (e.g., by e-mail or the most appropriate and relevant channel given the particular conditions of the client) and in the manner set out in the Disclosure of Interest and Fees and Charges Regulation 2011.

It is recommended that there be included on the front page of any mortgage document a clear warning in a statutorily prescribed format of the effects of a default on the relevant loan. The warning could be as simple as a clear statement in large print to the effect that a default means that debtors could lose their homes within 60 days of the notice of default. A similar statement of the effects of giving a guarantee should also be provided.

Consideration should be given to requiring banks to provide regular statements of account and to make information on account balances available on request. Information in statements could include, for example, details of opening and closing balances, debits and credits and especially of interest charges and fees and charges in the statement period. This notice should be available electronically or in person and, when that is not practicable, should at least be available to the customer on request. For rural areas, the usage of passbooks could be an effective way of meeting this need. Exceptions to the new requirement should be considered when appropriate. For example, there might be exceptions for fixed rate contracts, for loans that have been written off and for facilities where there have not been any debits or credits in the relevant period.

\section{MICROFINANCE SECTOR}

With the exception of the newly passed generic law on competition and consumer protection, there is no requirement for non-bank MFIs or SACCOs to disclose their rates or fees. Regulation No. 14/2011 on the Publication of Tariff on Interest Rates and Fees indicates it is only applicable to banks. The Microfinance Law, Microfinance Regulation and law Providing for the Establishment, Organization and Functioning of Cooperative Organization in Rwanda (known as the Cooperative Act) do not require MFIs or SACCOs to disclose fees, rates, penalties or changes to their clients and members. Article 46 of the Cooperative Act does provide for a member's rights in a cooperative, including information on the financial condition of the cooperatives, reports on the annual accounts and minutes of the annual general meeting. However, it is silent about financial consumer protection.

The current lack of clarity and transparency in MFIs, and to a lesser extent SACCO practices, limits the uptake of their services. Unlike some banks that post their fees and charges on websites and in lobbies as required, MFIs or SACCOs do not do so. That said, the loan contracts that were reviewed in SACCOs were succinct, included a key information box (albeit small) and have the principal information disclosed in Kiriwandan. Furthermore, in the cases in which members are not literate, once the loans are approved and before members sign for the loan, the manager 
meets with multiple members once to read them the disclosure terms and conditions. It is unclear if the same level of disclosure occurs pre-contractually and before the loan goes to the credit committee for review.

\section{Key Recommendation}

As with the banking recommendation above, BNR should require all fees, charges, penalties, rates and commission to be disclosed in plain language and in a manner understood by the average customer. Within the standardized calculation of effective interest rates, MFIs should specify the rates in declining balance basis. The use of key fact statements should be broadened from Umurenge SACCOs to other MFIs/SACCOs and follow a similar, standard format.

\section{INSURANCE SECTOR}

It is recommended that the BNR implement appropriate initiatives to ensure that consumers understand the insurance product they are acquiring, and the basic facts relevant to the coverage. This could include a Key Features Statement that explains the key features of the policies, or verbal disclosure in the case of consumers with lower levels of literacy. The key matters that could receive focus in consumer understanding include ensuring that the consumer understands that they have insurance, they know who their insurer is (particularly relevant when a consumer purchases insurance from a bank or other non-traditional intermediary), what their own obligations are, and how to access the benefits under the product.

It is recommended that BNR regularly publish an overview of the financial strength of the insurance industry, with key information that would include market share in key segments, solvency margins and regulatory capital. This would be in addition to the information that is currently published. It is also recommended that the Central Bank conduct an education campaign regarding the importance of an insurer's financial strength.

All information provided by an insurer should be accurate and not misleading and there should be a right of recourse if this obligation is breached. This recommendation is made notwithstanding that there are specific provisions in the Market Conduct Regulation dealing with misleading advertisements. ${ }^{12}$ The obligation to present accurate and complete information should be absolute, and the consumer should have clear recourses in the event that such information does not comply with regulations.

Information of the status of an intermediary should be provided in such a way that the consumer fully understands what entity the intermediary represents. This information should be given at the start of the relationship with the insured or at least prior to any advice or recommendation is provided. This recommendation is made because the current requirements do not make any provision for the timing or format of the disclosures that must be made by insurance intermediaries. However, the Intermediary Licensing Regulations and the Market Conduct Regulations do require that any broker or agent make disclosures about their statuses. Intermediaries must also clarify whether they are independent or associated with any insurance companies, and whether they are authorized to conclude insurance contracts. ${ }^{13}$

Brokers should be required to make upfront disclosures of the amount of any commission they receive for a product they recommend. This proposal is made because currently there is not an explicit requirement that insurance brokers disclose commissions. This is obviously important information necessary to assess any potential conflict of interest.

More specific regulatory guidance is needed to ensure that consumers are not misled about the potential investment returns for life investment products. For example, this could include a requirement that the insurer take into account the type of assets and the terms of the contract in making predictions about investment returns and a requirement for a clear statement that past investment performance is no indicator of future performance.

Consideration could be given to whether code or regulatory requirements could be implemented to heighten the likelihood of appropriate product recommendations, such as the conduct of a "fact find" about an insured's circumstances and needs. A fact-find, for example, could be in writing and retained for a specified period. Article 8 of the Market Conduct Regulation does not contain any specific requirement in this regard, although it deals generally with the issue of the information that must be obtained from the potential insured.

\footnotetext{
${ }^{12}$ Article 7.
}

${ }^{13}$ Articles 16 and 7 , respectively. 


\section{Business Practices}

\section{BANKING SECTOR}

\section{Fees and Interest Charges}

Rwanda does not at present have any restrictions on the fees that may be charged by banks for their Ioan or other facilities. On the contrary, Article 5 of the Disclosure of Interest and Fees and Charges Regulation 2011 provides the following: "The deposit and lending rates and the various fees in connection with the activity of banking intermediation may be freely agreed between the parties concerned."

However there are prepayment, account-closure and ATM fees and default interest charging practices that need to be addressed both to encourage competition and in the interests of financial inclusion and fairness generally. In this regard it is to be noted that numerous concerns were observed about these matters. Such practices include the charging of a fee of 5 percent of the outstanding balance on pre-payment of a loan and the charging of a fee of 10,000 RWF for closure of a savings account. Further, a fee of around 400 RWF is charged for use of another bank's ATM without the customer being told of the fee at the time of the transaction. The team was also told of a practice of charging a 2 percent fee on any withdrawal in a month after the first withdrawal. Such a high fee is likely to discourage use of accounts; it is also difficult to see how a percentage-based fee can be justified on a cost basis. Another concern is that the team was informed of a practice of charging default interest on the total outstanding balance of the relevant loan, i.e., not just on the amount in default. These practices need attention to encourage a competitive financial services market in Rwanda. A further consideration is that particularly high-transaction fees may be considered inconsistent with the government's financial inclusion objectives. For example, highdeposit, withdrawal and ATM fees on accounts to which G2P payments and conditional cash transfers (CCTs) are paid are a particular concern in this regard, especially when the accounts can only be accessed electronically.

\section{Key Recommendations}

Conduct further analysis of the suitability of current prepayment fees. Further analysis is necessary to determine the implications of fees on early repayment of installments and early repayment of the entire outstanding balance on the average consumer. However, there should be a consideration to allow for reasonable administrative costs relating to the prepayment and, for fixed rate facilities, a charge that takes into account differences between the interest rate payable under the facility and that prevailing at the time of the prepayment.

Account closure fees could be required to reflect the true cost of the closure. This would mean that these fees would only be able to be charged to the extent they reflect the reasonable administrative costs of closing the account. Further analysis on the costs of account closure and switching needs to be carried out to determine the implications of competition and to design remedial actions.

Default interest charges should only relate to the amount in default. Typically, these charges would only be on the amount in default (i.e., not on the entire outstanding balance) while the default continues.

ATM fees should be transparent to the customer when using ATMs. Consideration should be given to requiring customers to be given notice of the fees applicable to use a foreign ATM (i.e., an ATM operated by a bank that is not the customer's bank). This notice should be given on the ATM at the time of the transaction and the customer should have the option of not proceeding with the transaction if they do not wish to pay the fee.

\section{Total Cost of Credit Interest Rate}

At present there is no requirement for banks to publish a total cost of credit interest rate. A total cost of credit rate would show as a single rate the applicable interest rate and mandatory fees (such as a loan application fee) and charges (such as for a credit- life insurance premium). They are calculated based on a prescribed formula and for disclosure purposes can be calculated in relation to fixed term credit for specified loan amounts and terms of credit. 
Total cost of credit interest rates can be a useful means of helping consumers compare products and encourage competition. This is on the basis that a requirement to disclose a nominal interest rate by itself or even an effective interest rate that takes into account compounding is not adequate disclosure because it does not give consumers enough information to assess product affordability and suitability or to comparison shop. ${ }^{14}$

\section{Key Recommendations}

It is recommended that consideration should be given to requiring banks to:

- Include the total cost of credit interest rate in fixed rate loan contracts and in the key facts statement recommended above.

- Disclose the applicable total cost of credit interest rates in advertisements that refer to an interest rate on a fixed rate loan.

- Provide consumers with a schedule of total cost of credit interest rates based on specified loan amounts and terms.

- The total cost of credit rate should be accompanied by prescribed warnings of its limitations.

\section{Credit Bureau}

Rwanda has a new law regulating credit bureaus and one licensed credit bureau. The Credit Information Law is comprehensive with the usual, expected consumer protections. The only private credit bureau currently licensed in Rwanda is the Credit Reference Bureau (CRB) Africa. Banks and licensed MFIs are required to obtain a credit report from CRB when assessing an application for credit. Consumers have access and correction rights and there are detailed provisions relating to customer confidentiality and the use of credit bureau reports. Comprehensive guidelines and principles on credit reporting have been developed by the World Bank. ${ }^{15}$

However, it is not clear that consumers understand their rights under the Credit Information Law. There does not seem to have

\footnotetext{
${ }^{14}$ CGAP Designing Disclosure Regimes for Responsible Financial Inclusion, 2012.

${ }^{15} \mathrm{http}: / /$ siteresources.worldbank.org/FINANCIALSECTOR/Re sources/GeneralPrinciplesforCreditReporting.pdf.
}

been a widespread campaign by CRB about their activities and the protections in the CRB Act. There is also a concern about the reasonableness of the fees charged to individuals if they request a correction to information maintained about them on CRB's database, but the information is shown to be correct. The fee is RWF 50,000 if the customer is a bank customer and RWF 10,000 if the customer is an MFI customer.

\section{Key Recommendations}

CRB should conduct a public awareness campaign about CRB's activities. The design of effective methods for financial education can be informed by the new evidence and insights on financial education produced recently by the World Bank. $^{16}$

Consideration should be given to allowing one free request (subject to correction) of a report per year. This would be consistent with the World Bank's Credit Reporting Principles, $2011 .^{17}$

\section{Licensing of Debt Collectors}

Rwanda does not at present have any laws requiring debt collectors to be licensed or any laws for imposing controls over the activities of debt collectors. Collections Africa is currently the only debt collector operating in Rwanda and is a subsidiary of CRB. Arguably, debt collectors such as Collections Africa should be supervised, given the sensitivity of the information they handle and the commission incentives they have to take strong measures to collect debts. Further considerations in support of this view are that given the rapid expansion in the availability of retail banking services in Rwanda and the low levels of financial literacy there is a high risk of debtors not understanding their rights in relation to the collection of debts and thus a high risk of debtors being abused. The ability of the only collection company to access the CRB database is of significant concern because it is not apparent this is permitted under the Credit Information Law or is a good practice given the confidentiality of credit reports. There are detailed restrictions in the Credit Information Law pertaining to the purposes for which

\footnotetext{
${ }_{17}^{16}$ Additional information can be found in www. finlitedu.org . ${ }^{17}$ Page 50.
} 
credit reports can be used, and it is not clear that the practice detailed above is within those provisions. ${ }^{18}$

\section{Key Recommendations}

Debt collectors in Rwanda should be licensed and comply with specified business conduct rules. There should also be strict requirements to keep debtor information confidential.

The practice of accessing CRB's credit information database merits further review. In particular, there should be an assessment of whether it is permitted under the Credit Information Law.

\section{MICROFINANCE SECTOR}

There is currently no required or voluntary code of conducts in place for MFIs or SACCOs. Within MFIs and SACCOs there are instances of unclear and mis-represented information but not widespread consumer abuses The association of microfinance institutions (AMIR) oversees the process of implementing a code of conduct for its members. There have not been trainings for regulators or the $\mathrm{MFI}$ SACCO sectors on consumer protection. There are not any MFIs or SACCOs that have performed internal consumer protection assessments, have had external assessments, or been certified by the SMART campaign or others. One important observation in MFIs is the use of flat interest rates, as opposed to a declining rate of interest, by the three largest and most sophisticated MFIs (one of which is an MFI bank). Unlike Umurenge SACCOs, which use manual systems and arguably could provide a rationale for using flat interest rates, these three large socially oriented MFIs have relatively robust computer systems in place that could calculate interest on a declining balance. While not required by law or regulation, there are no $\mathrm{MFI}$ or SACCO disclosing loan commissions and fees, required security savings and costs of required insurance through an effective interest rate or total cost of credit.

Umurenge SACCOs disclose only monthly interest rates whereas most in the market use annual rates. These rates, fees and charges are disclosed to members in writing in Kiriwandan and verbally. Members receive a copy of the written and signed loan agreements. While amortization sche-

\footnotetext{
${ }^{18}$ Article 14.
}

dules are not provided, the interest rates are fixed and members pay the same amount each month that is disclosed. The fees and commissions at SACCOs were on average $1 \%$ lower than at other MFIs. Annual rates of interest were higher than at most banks, but Umurenge SACCOs are still growing their loan portfolios (only $30 \%$ of assets), have less collateral for loans, and many are losing their long-standing RCA; NPLs are rising and they need to continue charging rates that allow them to become profitable and afford new systems (i.e., credit bureau, IT). When looking at effective interest rates on a comparable declining balance, MFI rates are generally slightly higher than those at SACCOs are. Again, because no regulations exist for MFIs or SACCOs, any activity is permissible.

BNR does look at how rates and fees are being charged and calculated during onsite visits. BNR supervisory staff compares MFI/SACCO practices to internal policies during on-site examinations. Neither BNR nor RCA supervisory staff have received consumer protection training nor is such information included in their on- and offsite inspection manuals.

Some MFI banks charge fees to close savings accounts because they "want to discourage customers from leaving" and going to other institutions. In the current environment in which monthly maintenance fees for savings accounts exist, discouraging account closure encourages continuous fees for institutions. Most MFIs and SACCOs have monthly saving account maintenance fees that are lower than at banks despite having higher interaction time per customer than banks.

MFIs and SACCOs require credit life insurance for loans above a certain threshold. The requirement is disclosed to consumers, but commissions are not and some institutions have a sole source relationship with an insurance company. The largest MFI has a sister company that provides insurance but consumer could obtain their own policies separately.

Few data protection exists in MFIs and SACCOs. Although no extensive survey was conducted, instances of improper sharing of consumer's data in MFIs or SACCOs were not identified during field interviews. Nonetheless, the current practices with the new credit reference bureau revealed potential for data breaches. Some MFIs and SACCOs share employees' ID and passwords to access CRB Africa's systems. This affects traceability and breaches to the system, which could potentially generate identify theft problems and manipulation of confidential data. As there is no broad reaching data privacy and protection 
law currently to protect the sharing of consumers' loan or savings information outside of the credit bureau or electronic money transactions.

Collection practices by MFIs and SACCOs, as evidenced through field interviews, are in line with international best practices but varied among the different institutionas. The mission was unaware of any MFIs or SACCOs using the new collections agency. The most aggressive practices were among commercially oriented MFI banks. The team was unable to discern internal social pressure practices among group lending participants. The National Recovery Committee set up to recover loans following the failure of nine MFIs/SACCOs in 2006 has not met since February 2013 because the new minister of justice has not reconstituted it. Some of the 30 district-level recovery committees are still operating, but their usage is limited to MFIs and SACCOs. The recovery committee's actions are non-binding and when they cannot recover through moral suasion of the local police and vice-executive secretary (which chairs each district committee) matters are taken to courts. Because of limited IT capabilities and the nature of lending in rural areas, Umurenge SACCO are not registering collateral with $\mathrm{RDB}$ and utilizing the expedited process to recover collateral.

\section{Key Recommendations}

The general Financial Consumer Protection should include MFIs/SACCOs. Further analytical work is required to assess the needs in terms of institutional capacity at both the supervisory level and the MFI level. A standardized methodology is required for disclosing effective annual interest rates, the total cost of credit, terms and conditions, the right to statements, copies of contract, the terms and conditions of the loan and the privacy of data.

\section{INSURANCE SECTOR}

It is recommended that BNR consider working with the insurance industry to develop an insurers' code of conduct, which would cover such essential areas as customer service, disclosures, claims and complaints handling. This could be overseen by ASSAR, perhaps reporting to BNR on insurer compliance. The code would be made available to customers, such as on the insurer's website or provided with new policy documentation and should apply to all participants in the insurance value chain, including MFIs, SACCOs and banks.

Ideally there would be an express provision in the law making insurers liable for their agents' conduct in relation to the insured and especially in relation to anything agents say in respect of the relevant policy (for example, in relation to the returns from investment-oriented life policies). It may be implicit under the general law of contract in Rwanda that a principal is liable for the authorized conduct of its agents, but this needs to be expressly stated, and it needs to be made clear that liability will apply in respect to anything said by agents in relation to the insurance they are selling, even if what is said has not been authorized by the insurer. This is because agents are usually paid on a commission basis and accordingly have an incentive to "up-sell" policies.

It is recommended that BNR conduct research to identify the role of various participants in the insurance market (including MFls, banks, and SACCOs), because the level of understanding of participants is currently unclear. Once the range and roles of participants is understood, consideration should be given to ensuring that all such participants are subject to appropriate rules and oversight based on their contact with and influence on consumers. 


\section{E. Dispute Resolution Mechanisms}

\section{BANKING SECTOR}

\author{
Internal Complaints-Handling \\ Systems
}

Although all banks met by the mission team have internal complaint-resolution systems, these teams do not appear to meet all the requirements of the Customer Service Directive, and there appears to be minimal supervision by BNR. For example, it is not clear that complaints are redressed within the required 15 days or that management undertakes the required monitoring, analysis and management review of complaints. More fundamentally, the mission teams were frequently told that more needs to be done to improve customer service in relation to complaints (and other matters) and that BNR has limited resources available to monitor compliance with the directive, which may mean that systemic trends in complaints are missed.

\section{External Dispute Resolution Systems}

At present, there is not a single entity with responsibility for providing an external dispute resolution system in Rwanda. BNR does not have explicit power to deal with consumer complaints, although it receives around 10 per quarter (which it does not have the resources to deal with). The Office of the Ombudsman has power to fight against injustices in private administration and to receive and resolve related complaints. At present, these powers are rarely exercised in relation to financial services. The Ministry of Trade and Industry very occasionally deals with consumer complaints concerning financial services under its administration of the CCP Law. ${ }^{19}$ Consumers may bring cases to the commercial court where there is provision for simplified procedures to be applied at the preliminary hearing stage.

\footnotetext{
${ }^{19}$ The BNR Directive on Customer Service Delivery in Financial Institutions 2012 requires that regulated entities (which include banks) have an external dispute resolution system that meets specified international standards (but there is no such scheme in Rwanda). The Credit Information Systems Law contains provisions concerning customer complaints about information contained in a credit bureau's database $^{19}$ (Article 29).
}

There is, however, currently a law being considered by Parliament that would establish a new deputy ombudsman in the Office of the Ombudsman with specific responsibilities for mediating financial services disputes. It is anticipated that the new deputy ombudsman will supervise around five officers in a new unit within the Office of the Ombudsman. At the time of writing, details of the new law were not available. This proposal has been initiated by the BNR, which has been conducting training for the officers proposed to be working in the unit.

\section{MICROFINANCE SECTOR}

There is a confusing and unclear system for the resolution of financial consumer complaints and recourse for MFI/SACCO clients. The Rwanda Cooperative Agency claims to have a role in resolving disputes between SACCOs and their members. However, nothing in the 2008 Law "Establishing Rwanda Cooperative Agency (RCA) and Determining its Responsibilities, Organization and Function" or the 2007 Law "Providing for the Establishment, Organization and Functioning of Cooperative Organization in Rwanda" provides this power or duty to RCA. Despite it not being within the mandate of the Rwanda Cooperative Agency, they are handling 5-7 member complaints per month. The most frequent complaint (while not necessarily consumer protection related) is that SACCOs are not giving loans. BNR also receives 10 complaints per month on average but there are no internal procedures or processes.

Few MFIs and few SACCOs have a formal internal process for receiving, responding to and analyzing consumer complaints despite the current directive on customer service delivery. Only two out of six MFI/SACCOs interviewed had heard of the directive. BNR reports few institutions are providing the required quarterly reports. None of the MFIs or SACCOs visited had a formal written procedure for handling complaints. All of the institutions had an informal internal escalation procedure for complaints but none of them offered their clients or members additional external avenues for lodging a dispute with BNR, RCA or the ombudsman. 
None of the MFIs or SACCOs (nor BNR or RCA) visited had a systematic process for tracking, categorizing, analyzing and reporting on disputes. The Directive on Customer Service Delivery requires this, but the team found little awareness of this directive in institutions, and few quarterly reports were filed by any financial institutions related to the directive according to BNR. This directive is scattered in orientation, covering customer service, consumer protection and workplace practices. It has unrealistic benchmarks for many of the measures (e.g., maximum wait times of three minutes in lobbies and maximum call times of two minutes for dealing with customers by phone) and other measures are micromanaged and burdensome to track and measure (e.g., status of washrooms and whether staff is smiling).

\section{INSURANCE SECTOR}

Market conduct regulations require the establishment of an internal dispute resolution procedure. In addition to requirements under the directive, under the insurance Market Conduct Regulations, insurers are required to have an internal dispute resolution process that addresses policyholders' complaints in a timely and fair manner, and the insurer must communicate the processes and procedures to policyholders. Other potential complainants are not mentioned. Brokers must also comply with certain basic requirements for complaints handling. Complaints must be accepted by phone or in writing, must be dealt with at a suitably senior level, and the broker must have a system for recording and monitoring them. ${ }^{20}$

\section{KEY RECOMMENDATIONS}

It is proposed that regulated financial services providers, including banks, insurers, insurance brokers and private pension providers be required to publish details of their internal complaints procedures. Details about complaints procedures should be made widely available to customers, and institutions would need to maintain and provide to BNR detailed statistics about the number, type and origin of customer complaints and the time taken to respond to them. It is recommended that these be formalized in a law or regulation and the existing directive be repealed. These recommendations are

\footnotetext{
${ }^{20}$ Article 7 Broker Code of Conduct.
}

made against the background of the proposal that the Office of the Ombudsman take on new responsibilities to deal with complaints about financial services. It is particularly important in this context that banks have comprehensive procedures for considering complaints internally. Otherwise the Office of the Ombudsman is likely to be inundated.

It is recommended that the proposed new arrangements for the Office of the Ombudsman be reviewed to ensure that the ombudsman has appropriate powers and that the scheme is otherwise designed to meet international best standards for financial ombudsmen schemes. In particular it is proposed that:

- The ombudsman have clear and specific power (as well as the resources) to provide a dispute resolution service in relation to financial services and to make decisions that are binding on the financial institution concerned (but not on the customer).

- The new service should be designed to ensure that it is a clear, affordable and transparent third party dispute resolution system. ${ }^{21}$

Consolidate dispute resolution for the financial sector in a well-trained, appropriately staffed and sufficiently empowered unit of the national ombudsman. This includes making its findings binding and ensuring that RCA and BNR relinquish these dispute resolution roles. As indicated above the Directive on Customer Service Delivery should be withdrawn and replaced.

\footnotetext{
${ }^{21}$ Guidance in this regard may be obtained from the World Bank's recent publication on Resolving Disputes between Consumers and Financial Businesses: Fundamentals for a Financial Ombudsman: http://www. networkfso.org/Resolving-disputes-betweenconsumers-and-financial-businesses Fundamentals-for-afinancial-ombudsman The-World-Bank January2012.pdf
} 
To further improve access to justice for citizens, governments often take further steps to provide alternative dispute resolution systems that allow for an out-of court-decision to be taken when parties fail to arrive voluntarily to a settlement on a complaint. Generally, there are three models of financial ombudsman applied as follows:

\section{Ombudsmen established by financial services associations}

Decision by such an ombudsman is not legally binding but his findings are usually respected by financial institutions voluntarily as a part of self-regulation of the market, sometimes with financial companies even publicly declaring to be bound by the ombudsman's decisions. In countries such as Germany, an industry-based ombudsman structure for each part of the financial sector has proven effective. However, in the case of such an ombudsman structure established by a professional association, attention should be paid to the presence of conflicts of interest. Also, consumers may perceive the ombudsman as someone who will always decide in favor of the financial institution and against the consumer.

\section{Statutory independent ombudsmen}

In this approach, the ombudsman has functions and powers set up by national laws and members appointed by government authority. For example, the UK established a scheme by law to function as an independent institution, while Armenia legally requires financial institutions to join a central-bank-approved ombudsman scheme with binding rules for all member institutions. A single statutory ombudsman would make it easy for consumers to identify to which agency they should submit their inquiries or complaints. While this model has the advantage of clearly defined objectives and mandates, the challenge is to provide the new ombudsman with sufficient authority and resources.

\section{The ombudsman structure should be established within the regulatory and supervisory agency}

A third model is the set-up of a financial ombudsman structure within a regulatory and supervisory agency. For example, in the case of Bosnia Herzegovina, a banking system ombudsman has been established as an independent organizational unit within the Banking Agency of the Republic of Srpska. While this model has the advantage of using existing institutional arrangements to build upon, the challenge is to ensure the independence of such an ombudsman structure and avoid conflicts of interest. 


\section{F. Consumer Awareness and Financial Education}

Ongoing initiatives on financial education demonstrate the government's commitment to improve financial literacy and expand access to financial services. The National Financial Education Strategy, BNR's Financial Awareness Strategy, the Maya Declaration, presence within FSDP II and quarterly Access Forums in each district for all financial institutions and local businesses all demonstrate the government's interest and commitment to financial awareness and access. However, further efforts are needed to educate clients regarding their rights and responsibilities as financial consumers. The fragmented recourse system and weak regulatory environment makes it difficult to educate consumers on their rights.

Socially oriented MFI, SACCOs and their associations have in place programs to educate clients on financial services topics. Most of the education is product oriented relating to how to prepare for taking a loan, benefits of savings and understanding the financial system. AMIR has a program specifically oriented for educating youth in schools on basic financial services issues and then linking schools to local VSLAs.

Support should be provided to credible and independent research or consumer advocacy groups that can help consumers compare offering and prices. This information should go beyond product and budgeting training to include information on consumers' rights for recourse, to receive statements on their accounts, receive information on products before committing to them, to be treated with respect and in monitoring or correcting their information in the credit bureau.
The specific consumer protection needs of lowincome households who take out micro insurance should be considered as the market develops. In particular, regard should be given to their needs for education, the nature of risk-based insurance products and the establishment of clear rules and procedures to file a claim. Insurers might also be encouraged to provide a simplified (one page) policy proposal in this market.

The FSDP II proposal for professional training of technical staff and insurance intermediaries should be implemented. Insurance intermediaries (brokers, agents, loss adjusters) and technical staff employed by the insurers will be required to have a professional qualification such as the Certificate of Proficiency in Insurance, which is available with various specializations. 


\section{Annex I. List of Recommendations}

\section{Institutional Arrangements}

- Clarify the roles of BNR, ombudsman, the forthcoming Competition and Consumer Protection Regulatory Body and RCA (for SACCOs) as it relates to consumer-

BNR MT protection rule making, enforcement and dispute resolution in the financial sector.

- $\quad$ BNR should be given primary responsibility for supervision of laws and regulations applicable to consumer protection in the financial sector.

BNR

- $\quad$ BNR staff should receive training on consumer protection issues. A separate unit within BNR that has primary responsibility for supervising consumer protection laws may be

BNR considered.

\section{Legal and Regulatory Framework}

- Consider implementing a cohesive Financial Consumer Protection framework that applies to banks, MFIs, SACCOs, insurance companies, securities, and pension

BNR schemes as well as the brokers or agents of such institutions.

- Regulation and supervision of financial consumer protection laws should be properly resourced and separated from the prudential function.

- Enact provisions that provide a comprehensive regime for transparency and fairness in consumer contracts and related business practices

- Consider conducting further analytical work to assess the need to implement a personal insolvency law to provide for the degree of recourse and assets that can be claimed upon seizure of collateral.

- Clarify the powers of the Office of the Ombudsman in respect to financial services. In particular, it is proposed that the ombudsman should have clear power to make binding decisions on financial services disputes.

- Consider the revision of the CPP law and the BNR law to clarify their jurisdictions in the financial services sector.

MOJ

MT

\section{Transparency and Disclosure of Information}

- Require all fees, charges, penalties, rates and commissions to be disclosed in a manner understood by the average consumer.

BNR

ST

- Require disclosure of an effective interest rate for comparison purposes and on the basis of declining balances.

- Require a key facts statement for all basic consumer finance products.

- Review of the mortgage law to include a clear warning regarding the effect of a default on a relevant loan.

- Review of the EFT regulations regarding disclosure of information.
BNR

BNR

BNR, MoJ, Minecofin

BNR MT 
- Require financial institutions to publish the details of their licenses in their advertising and marketing materials.

BNR MT

\section{Business Practices}

- $\quad$ Promote competition in the banking space by enabling consumers in banks, MFIs and SACCOs to close deposit accounts and pre-pay or move loans with minimal time and cost burden.

$\mathrm{BNR} / \mathrm{RDB}$

- Oblige financial institutions, as a banking license condition, to ensure that their staff, third party agents and authorized representatives are adequately trained and have the

BNR skills, experience and professional qualifications to competently carry out their functions

- $\quad$ Require that mortgagors be given warnings about the consequences of default (including the possibility of losing their homes) and otherwise ensure there is sufficient due process in the repossession of collateral.

- Develop a new data protection law or at least regulations on protection and confidentiality of financial consumers' personal data

\begin{tabular}{cc} 
MoJ, BNR & MT \\
BNR BNR & MT \\
BNR & $M T$ \\
CRB & $M T$ \\
BNR & \\
\hline
\end{tabular}

- Industry codes of conduct should be supported with treatment of disclosure, complaints, product appropriateness and other business areas strengthened, enforced and widely disseminated.

AMIR, ASSAR

\section{Dispute Resolution Mechanisms}

- Consolidate dispute resolution for the financial sector in a well-trained, appropriately staffed and sufficiently empowered unit of the national ombudsman. This includes making its findings binding and ensuring that RCA and BNR relinquish these roles.

OMB

- Consolidate, analyze and publish statics on consumer complaints.

OMB, BNR

MT

\section{Financial Education}

- Continue with financial awareness campaigns related to the use of financial products and basic financial concepts that are understandable for the average consumer.

BNR

- Encourage financial institutions to put in place programs to educate clients on financial services topics.

GoR

- Invest resources in financial literacy initiatives.

GoR 


\section{Annex II. Financial Sector Development (FSDP II) - Action Plan}

\begin{tabular}{|c|c|c|c|}
\hline Sub-program & Outputs & $\begin{array}{l}\text { Completion } \\
\text { Date }\end{array}$ & $\begin{array}{l}\text { Implementing } \\
\text { Institutions }\end{array}$ \\
\hline \multicolumn{4}{|c|}{ Program 1: Action Plan for Financial Inclusion } \\
\hline $\begin{array}{l}\text { National financial } \\
\text { education and literacy } \\
\text { strategy }\end{array}$ & $\begin{array}{l}\text { - National financial education policy } \\
\text { and strategy completed } \\
\text { - Roadmap in place to achieve } \\
\text { specific objectives over } 5 \text { years. } \\
\text { - Institute of Entrepreneurship, } \\
\text { Cooperatives and Microfinance } \\
\text { established }\end{array}$ & $\begin{array}{l}\text { - June } 2014 \\
\text { - June } 2014 \\
\text { - June } 2015\end{array}$ & $\begin{array}{l}\text { Ministry of Finance and } \\
\text { Economic Planning } \\
\text { National Bank of Rwanda }\end{array}$ \\
\hline Micro-insurance & $\begin{array}{l}\text { - Micro-insurance diagnostic } \\
\text { completed }\end{array}$ & - June 2014 & $\begin{array}{l}\text { National Bank of Rwanda } \\
\text { Access to Finance } \\
\text { Rwanda }\end{array}$ \\
\hline $\begin{array}{l}\text { Strengthen the } \\
\text { Umurenge SACCO } \\
\text { program-phase } 1\end{array}$ & $\begin{array}{l}\text { - Substantial technical secretariat in } \\
\text { place to support technical steering } \\
\text { committee, coordinating and } \\
\text { implementing technical assistance } \\
\text { for SACCOs and MFls } \\
\text { - Financially sustainable district } \\
\text { SACCOs established in every } \\
\text { district } \\
\text { - Standardized hardware, } \\
\text { accounting, reporting, IT and MIS } \\
\text { in use in all SACCOs and their } \\
\text { branches } \\
\text { - RCA cooperative policies and } \\
\text { procedures issued to SACCOs on } \\
\text { non-financial issues } \\
\text { - Work-out unit established to deal } \\
\text { with weak SACCOs and MFIs } \\
\text { CGAP management tool in use in } \\
\text { all SACCOs and their branches }\end{array}$ & $\begin{array}{l}\text { - June } 2013 \\
\text { - December } \\
2014 \\
\text { - June } 2015 \\
\text { - June } 2013 \\
\text { - December } \\
2013 \\
\text { - December } \\
2014\end{array}$ & $\begin{array}{l}\text { Ministry of Finance and } \\
\text { Economic Planning } \\
\text { National Bank of Rwanda } \\
\text { Rwanda Cooperative } \\
\text { Agency }\end{array}$ \\
\hline $\begin{array}{l}\text { Umurenge } \\
\text { SACCOs-phase } 2\end{array}$ & $\begin{array}{l}\text { - National structure and } \\
\text { implementation plan developed after } \\
\text { study overseen by technical } \\
\text { committee and stakeholder input } \\
\text { - National structure operational, } \\
\text { providing services to SACCOs }\end{array}$ & $\begin{array}{l}\text { - June } 2016 \\
\text { - June } 2017\end{array}$ & $\begin{array}{l}\text { Ministry of Finance and } \\
\text { Economic Planning } \\
\text { National Bank of Rwanda }\end{array}$ \\
\hline $\begin{array}{l}\text { Strengthen } \\
\text { Supervisory and } \\
\text { Regulatory } \\
\text { Environment for } \\
\text { SACCOs and MFIs }\end{array}$ & $\begin{array}{l}\text { - External audits of all SACCOs, older } \\
\text { SACCOs and MFIs completed by } \\
\text { BNR approved auditors } \\
\text { - SACCOs and MFIs reporting to the } \\
\text { CRB and using CRB reports in credit } \\
\text { adjudication }\end{array}$ & $\begin{array}{l}\text { - June } 2014 \\
\text { - June } 2015\end{array}$ & National Bank of Rwanda \\
\hline
\end{tabular}




\begin{tabular}{cccc}
\hline Sub-program & Outputs & $\begin{array}{c}\text { Completion } \\
\text { Date }\end{array}$ & $\begin{array}{c}\text { Implementing } \\
\text { Institutions }\end{array}$ \\
\hline
\end{tabular}

Program 2: Developing Institutions, Markets and the Supporting Infrastructure

\begin{tabular}{|c|c|c|c|}
\hline Insurance & $\begin{array}{l}\text { Rwanda specific mortality (life) } \\
\text { tables prepared } \\
\text { BNR capable of supervising annuity } \\
\text { risks } \\
\text { - Local educational institution } \\
\text { delivering professional courses for } \\
\text { CoP or equivalent }\end{array}$ & $\begin{array}{l}\text { - } \text { December } \\
2015 \\
\text { - } \\
\text { December } \\
2014 \\
\text { - } \\
2014 \\
2014\end{array}$ & $\begin{array}{l}\text { Ministry of Finance and } \\
\text { Economic Planning } \\
\text { National Bank of Rwanda } \\
\text { Rwanda Social Security } \\
\text { Board } \\
\text { Association des Assureurs } \\
\text { du Rwanda } \\
\text { School of Finance and } \\
\text { Banking }\end{array}$ \\
\hline Pensions-RSSB & $\begin{array}{l}\text { - Virtual holding company concept } \\
\text { implemented with separate accounts } \\
\text { for pensions, medical, and allocation } \\
\text { of overhead } \\
\text { - Separate investment policies } \\
\text { established for pension and medical } \\
\text { funds } \\
\text { - Actuarial studies for pension and } \\
\text { - Medical plans complete } \\
\text { - Management regularly receiving } \\
\text { analytical MIS reports } \\
\text { Rolling cash management plans in } \\
\text { place } \\
\text { Liquidity bucket gap analysis } \\
\text { completed on regular basis }\end{array}$ & $\begin{array}{l}\text { - June } 2013 \\
\text { - June } 2013 \\
\text { - June } 2013 \\
\text { - June } 2013 \\
\text { - June } 2013 \\
\text { - June } 2013\end{array}$ & $\begin{array}{l}\text { Ministry of Finance and } \\
\text { Economic Planning } \\
\text { Rwanda Social Security } \\
\text { Board }\end{array}$ \\
\hline Pensions-Private & $\begin{array}{l}\text { Pension law provides appropriate } \\
\text { legal foundation for private pensions } \\
\text { Licensing, prudential and } \\
\text { supervisory regime for private } \\
\text { pensions in place after legislation } \\
\text { enacted }\end{array}$ & $\begin{array}{l}\text { - June } 2013 \\
\text { - June } 2013\end{array}$ & $\begin{array}{l}\text { Ministry of Finance and } \\
\text { Economic Planning } \\
\text { Ministry of Finance and } \\
\text { Economic Planning } \\
\text { National Bank of Rwanda }\end{array}$ \\
\hline Payment System & $\begin{array}{l}\text { - Interoperability among ATMs, POS } \\
\text { and MMT systems } \\
\text { - Operational manual for CSD } \\
\text { completed - RIPPS } \\
\text { - National Payment System } \\
\text { Framework and Strategy updated }\end{array}$ & - June 2013 & $\begin{array}{l}\text { National Bank of Rwanda } \\
\text { Rwanda Bankers' } \\
\text { Association } \\
\text { Mobile Network Operators }\end{array}$ \\
\hline Capital Markets & $\begin{array}{l}\text { BNR securities depository and other } \\
\text { EAC depositories connected } \\
\text { - Investor compensation fund } \\
\text { established }\end{array}$ & $\begin{array}{l}\text { - December } \\
2014 \\
\text { - June } 2013\end{array}$ & $\begin{array}{l}\text { Capital Market Authority } \\
\text { Rwanda Stock Exchange } \\
\text { National Bank of Rwanda }\end{array}$ \\
\hline Stock Exchange & $\begin{array}{l}\text { - Public awareness campaign on } \\
\text { investing in securities complete } \\
\text { - Business information exchange for } \\
\text { venture capital, SMEs and investors } \\
\text { established } \\
\text { - Five-year plan for RSE financial } \\
\text { sustainability completed }\end{array}$ & $\begin{array}{l}\text { - June } 2014 \\
\text { - June } 2014 \\
\text { - June } 2014\end{array}$ & $\begin{array}{l}\text { Capital Market Authority } \\
\text { Rwanda Stock Exchange } \\
\text { Ministry of Trade and } \\
\text { Industry }\end{array}$ \\
\hline
\end{tabular}




\begin{tabular}{|c|c|c|c|}
\hline Sub-program & Outputs & $\begin{array}{l}\text { Completion } \\
\text { Date }\end{array}$ & $\begin{array}{l}\text { Implementing } \\
\text { Institutions }\end{array}$ \\
\hline $\begin{array}{l}\text { Bond Market } \\
\text { Development- } \\
\text { developing the } \\
\text { investor base }\end{array}$ & $\begin{array}{l}\text { - Ongoing "road show" presentations } \\
\text { to promote Rwandan market } \\
\text { - Electronic bond delivery and custody } \\
\text { within the EAC }\end{array}$ & $\begin{array}{l}\text { - June } 2014 \\
\text { - June } 2014\end{array}$ & $\begin{array}{l}\text { Ministry of Finance and } \\
\text { Economic Planning } \\
\text { National Bank of Rwanda }\end{array}$ \\
\hline $\begin{array}{l}\text { Bond Market } \\
\text { Development- } \\
\text { Private Issuance }\end{array}$ & $\begin{array}{l}\text { - Legal underpinnings for } \\
\text { securitization in place-Trust Law } \\
\text { and provisions for SPVs }\end{array}$ & - June 2013 & $\begin{array}{l}\text { Capital Market Authority } \\
\text { National Bank of Rwanda }\end{array}$ \\
\hline $\begin{array}{l}\text { Creditor Rights and } \\
\text { Insolvency }\end{array}$ & $\begin{array}{l}\text { - Tax regime does not penalize debt } \\
\text { restructuring } \\
\text { - Law permits informal workouts to be } \\
\text { formalized into a restructuring plan } \\
\text { and expedited } \\
\text { - Composition of creditors' committees } \\
\text { restriction to only creditors }\end{array}$ & $\begin{array}{l}\text { - June } 2014 \\
\text { - June } 2014 \\
\text { - June } 2014\end{array}$ & $\begin{array}{l}\text { Development Bank of } \\
\text { Rwanda } \\
\text { Rwanda Revenue } \\
\text { Authority } \\
\text { National Land Centre }\end{array}$ \\
\hline \multicolumn{4}{|c|}{ Program 3: Investment and Savings to Transform the Economy } \\
\hline $\begin{array}{l}\text { SME and Agricultural } \\
\text { Finance }\end{array}$ & $\begin{array}{l}\text { - } \quad \text { BDF guarantee scheme restructured } \\
\text { to be regulated as a financial } \\
\text { institution } \\
\text { - } \quad \text { Export guarantee facility available to } \\
\text { small borrowers } \\
\text { - Guarantee facility established for } \\
\text { coffee and tea production with } \\
\text { extended grace periods } \\
\text { - } \text { Agricultural/SME finance study } \\
\text { focusing on the demand side } \\
\text { completed } \\
\text { Warehouse Receipts Act and } \\
\text { regulations enacted } \\
\text { Index-based crop yield insurance } \\
\text { tracking system in place } \\
\text { Training programs delivered for bank } \\
\text { officers in providing agricultural } \\
\text { credit }\end{array}$ & $\begin{array}{lc}\text { - } & \text { June } 2014 \\
\text { - } & \text { June } 2014 \\
\text { - } & \text { June } 2015 \\
\text { - } & \text { June } 2015 \\
\text { - } & \text { June } 2017 \\
\text { - } & \text { June } 2016 \\
\text { - } & \text { June } 2015\end{array}$ & $\begin{array}{l}\text { Business Development } \\
\text { Fund } \\
\text { Rwanda Development } \\
\text { Bank } \\
\text { Ministry of Trade and } \\
\text { Industry } \\
\text { Rwanda Bankers' } \\
\text { Association } \\
\text { Ministry of Agriculture and } \\
\text { Animal Resources }\end{array}$ \\
\hline Housing Finance & $\begin{array}{l}\text { - Cell-based real estate value } \\
\text { reference system operational. } \\
\text { BRD housing finance strategy } \\
\text { focusing on mid-income housing } \\
\text { complete } \\
\text { - Training programs delivered for bank } \\
\text { officers in providing housing } \\
\text { financing } \\
\text { - National strategy for affordable } \\
\text { housing completed }\end{array}$ & $\begin{array}{l}\text { - } \quad \text { June } 2017 \\
\text { - } \quad \text { June } 2013 \\
\text { - June } 2015 \\
\text { - June } 2014\end{array}$ & $\begin{array}{l}\text { Rwanda Housing Authority } \\
\text { Rwanda Revenue } \\
\text { Authority } \\
\text { Rwanda Development } \\
\text { Board } \\
\text { Rwanda Bankers' } \\
\text { Association } \\
\text { Rwanda Development } \\
\text { Bank } \\
\text { Rwanda Social Security } \\
\text { Board }\end{array}$ \\
\hline \multicolumn{4}{|c|}{ Program 4: Protecting Consumers and Maintaining Financial Stability } \\
\hline Consumer protection & $\begin{array}{l}\text { - Financial sector unit established in } \\
\text { the Office of the Ombudsman }\end{array}$ & - June 2013 & $\begin{array}{l}\text { Ombudsman } \\
\text { National Bank of Rwanda }\end{array}$ \\
\hline
\end{tabular}




\begin{tabular}{|c|c|c|c|}
\hline Sub-program & Outputs & $\begin{array}{l}\text { Completion } \\
\text { Date }\end{array}$ & $\begin{array}{l}\text { Implementing } \\
\text { Institutions }\end{array}$ \\
\hline $\begin{array}{l}\text { Updating the } \\
\text { regulatory } \\
\text { framework-banking }\end{array}$ & $\begin{array}{l}\text { - LOB amendments reflecting all } \\
\text { specific FSDP II actions ready for } \\
\text { submission to parliament } \\
\text { - } \quad \text { New and revised regulations ready } \\
\text { for gazetting following enacting of } \\
\text { LOB amendments } \\
\text { - } \text { Bank prudential standards aligned } \\
\text { with EAC agreed convergence } \\
\text { - New and revised bank reports and } \\
\text { formats in place } \\
\text { - Revised bank chart of accounts } \\
\text { reflect IFRS and new reporting } \\
\text { formats } \\
\text { - National Bank of Rwanda law } \\
\text { revised to implement FSAP } \\
\text { recommendations }\end{array}$ & $\begin{array}{l}\text { - June } 2013 \\
\text { - June } 2014 \\
\text { - June } 2014 \\
\text { - June } 2015 \\
\text { - June } 2015 \\
\text { - December } \\
2014\end{array}$ & National Bank of Rwanda \\
\hline $\begin{array}{l}\text { Updating the } \\
\text { regulatory } \\
\text { framework- } \\
\text { insurance }\end{array}$ & $\begin{array}{l}\text { - Appropriately different regulations for } \\
\text { life and non-life insurers in place, } \\
\text { including capital, solvency and } \\
\text { investment guidelines }\end{array}$ & - June 2014 & National Bank of Rwanda \\
\hline Contingency planning & $\begin{array}{l}\text { - High level coordinating committee } \\
\text { established and operating pursuant } \\
\text { to TOR and MOUs with participating } \\
\text { institutions } \\
\text { - Generic contingency plan in place to } \\
\text { address financial instability } \\
\text { - Generic contingency plan in place to } \\
\text { deal with a failing financial institution } \\
\text { - Resolution framework in place } \\
\text { clarifying that the financial institution } \\
\text { laws take precedence over the } \\
\text { general insolvency law, and } \\
\text { providing full powers to quickly } \\
\text { impose resolutions to protect } \\
\text { depositors and financial stability } \\
\text { New deposit insurance law is fully } \\
\text { consistent with provisions of the LOB } \\
\text { and LMO }\end{array}$ & $\begin{array}{l}\text { - June } 2014 \\
\text { - June } 2015 \\
\text { - June } 2015 \\
\text { - June } 2014 \\
\text { - June } 2014\end{array}$ & $\begin{array}{l}\text { Capital Market Authority } \\
\text { National Bank of Rwanda } \\
\text { Ministry of Finance and } \\
\text { Economic Planning } \\
\text { Ministry of Trade and } \\
\text { Industry }\end{array}$ \\
\hline $\begin{array}{l}\text { Building Supervisory } \\
\text { Capacity }\end{array}$ & $\begin{array}{l}\text { RBS framework and all supervision } \\
\text { manuals and procedures revised for } \\
\text { consistency and full alignment with } \\
\text { laws, regulations and BNR policies }\end{array}$ & - June 2014 & National Bank of Rwanda \\
\hline
\end{tabular}

Source: MINECOFIN 

